\title{
A CRITICAL ANALYSIS OF THE UN INSTRUMENTS AGAINST TERRORIST FINANCING
}

\author{
Iffat NAHEED, PhD student \\ National University of Political Studies and Public Administration \\ Bucharest/Romania
}

\begin{abstract}
Terrorist financing with its different modes has become a core area of interest for researchers and policy makers around the world. With the passage of time the troika of terrorist financing; money laundering as a means for financing terror; and transnational organized crime has become a new equation to be considered for possible eradication. As terrorist financing has assumed complexities worldwide, so has the global response for countering it gained more legal maturity. In 2006, the adoption of "Global Counter Terrorism Strategy" aimed at strategizing policies and actions for combating Terrorism and especially Terrorism Financing. In 2009, 'International Convention for the Suppression of Financing of Terrorism' largely filled the lacuna in identifying terrorist financing as a criminal offence. This paper is aimed at critically analysing the different UN instruments for countering terrorist financing along with the challenges encountered in their implementation. It assesses that one of the most difficult aspects in countering terrorist financing remains the manner in which different UN Member States synchronize these instruments with their domestic legal framework. Another complicating factor remains the ever-evolving complexity penetrating into terror financing.
\end{abstract}

Keywords: counter terrorism; money laundering; terrorist financing; terrorist financing Convention; transnational organised crime; UN Global Counterterrorism Strategy (UNGCTS). 


\section{INTRODUCTION}

This paper analyses some critical areas of terrorist financing and different UN instruments devised to address this grave challenge. Briefly introducing the term "terrorist financing" and an overview of the recent situation created by the issue of terrorist financing, the paper throws light on the difficulties in terms of defining "terrorism" and its impact on the counter terrorist financing measures. It also undertakes a brief discussion on different modes of terrorist financing and techniques used by terrorists for collecting, storing and moving the funds to be utilized in financing of terrorist activities. This study further focuses on the nexus between terrorist financing, money laundering and organized crime. The financing of some terrorist organizations like Al-Qaida and ISIL is also described briefly. The main focus of the study is Counter terrorist financing efforts from United Nations through its different instruments. The major shortfalls and challenges in the implementation of obligations and provisions of UNSC devised instruments and risk assessments related to their implementation are also analysed critically. For the purposes of this study, qualitative research methodology has been adopted where a critical review of different UN resolutions and mechanisms has been undertaken.

In fact, the efforts to counter terrorism should be formulated in a way to meet the threat effectively. It seems obvious that if the threat of terrorism has attained a globalized nature, the counter terrorism efforts should also be global. In this way it might be anticipated that counter terrorism policy tasks like intelligence operations, law enforcement, use of military powers and more specifically the financial controls should be pursued multilaterally in a more cooperative way. So, the extent and level of this multilateral cooperation specifically through the platform of United Nations along with its successes and failures provides the main background of this article. For this purpose, I have discussed the cooperation in terms of counter terrorism chronologically. By analysing the patterns of cooperation among states on discrete tools of counter terrorism policy, a mixed approach is observed discerning the following trends. The degree of multilateral cooperation can vary over time as well as with different aspects of counter terrorism policy as some of its tools require a low level of 
multilateral cooperation because of the involvement of many actors like law enforcement agencies and national-level intelligence. This study shows that a high level multilateralism is utilized in the field of counter terrorism financing in the post $9 / 11$ period and the existing institutions and organizations particularly United Nations have been adapted to enhance the targeted tasks.

In regard to the multilateral cooperation, this study is built on an "analytically eclectic" approach utilizing realist, liberal and constructivist theories. For realists, multilateralism yields from the process of contestation among states as states tend to pursue narrowly defined national interests and assume that other states may benefit more from cooperation. Liberals believe that cooperation has positive prospects. They consider multilateralism being a solution to the common problem despite the states being self interested actors. According to constructivists, multilateralism is considered an outcome of shared principles and interests that states internalize as norms. Though, none of the above approaches fits perfectly and concept of multilateralism in case of counter terrorism seems more political in nature, the significance of cooperation cannot be denied. In this situation when states do not tend to act multilaterally, the cases of successful cooperation can be interpreted on the basis of theories of IR. Multilateralism being a contested concept among the scholars can be better explained on the basis of theoretical approach of the analyst whether constructivist, liberal or realist. Constructivist arguments interpret that cooperation is possible in specific fields of counter terrorism policy and issue area experts who cooperate by sharing their professional skills and knowledge in highly specialized domains, which is more evident in the field of counter terrorist financing (Romaniuk 2010).

Keohane (2009) defines multilateralism as "the practice of coordinating national policies in groups of three or more states through ad hoc arrangements or by means of institutions", which is a liberal-institutional interpretation of international cooperation. This article reflects the liberal-institutional approach more than the realist and constructivist approaches. However, realists are totally skeptical to Keohane's idea due to security dilemma and anarchic nature of international system and they take cooperation as an exception instead of rule. For realists, multilateral cooperation is imposed, contested and results in forum 
shopping. Liberals believe in emergence of regimes which is a form of multilateral cooperation through the use of game theory even in the presence of "Prisoner's dilemma". So, liberals support the idea of multilateral cooperation as shared benefits through existing institutions like United Nations in case of counter terrorist financing.

Terrorist Financing is the main tool for the terrorist groups to prosper and therefore needs to be countered efficiently to combat terrorism in a successful manner. With the passage of time, terrorists have evolved their capabilities along with diversification of the sources of their funds and instruments to transfer them around the world. A strong political commitment at all levels and coordination among law enforcement institutions as well as financial intelligence entities is required to effectively counter the challenges posed by terrorist financing. The transnational nature of terrorist financing makes it essential to be analysed and assessed from a global perspective. The terrorist threat has a direct impact on security. Resultantly, an international approach is obligatory for countering terrorism and terrorist financing (UNODC 2018). There are thirteen UN conventions and protocols against terrorism; however, there is no single universally adopted definition of terrorism (Realuyo 2011).

Given the global nature of contemporary terrorism, it is vital to ensure uniform international implementation of Counter Terrorist Financing (CTF) measures. However, this does not seem to be an easy task due to the never-ending debate about defining the terrorism, which has complicated both academic research and CTF efforts at international level. Due to the divergence found in organizational forms of terrorist groups and the methods they use for collecting, moving and saving their funds, it has become a Global challenge to counter terrorist financing completely and effectively. Before 9/11, terrorist activities were financed locally (i.e. at national level) by donations and criminal activities or internationally sponsored by some States in pursuit of their specific foreign policy agendas. The post $9 / 11$ progress and coordination among terrorist groups globally has made them achieve the status of self supporting 'nomadic terrorist networks' that can operate between different jurisdictions and carry out their operations through active cells located in another region. These financial safe havens have caused complications in counter terrorist financing efforts. To 
drain out the finances of terrorists and their groups, 'Smart Sanctions Model' by UN Security Council has shaped CTF efforts worldwide with successes to a large extent (Bures 2012).

The 'smart sanctions' or 'targeted sanctions' are the corner stone of UN strategy to 'breach the state veil' and identify the individuals to bring them to justice. There is no broadly accepted definition of 'targeted sanctions' but these include the measures inter alia freezing of assets, limitation of access to foreign financial markets, trade restrictions on arms and luxury articles, flight bans, restrictions on visas, international travel bans, and restrictions on educational opportunities in compliance with UN Security Council Resolutions for specific individuals while avoiding their impact on the rest of the population in the "targeted State" (Shillito 2015).

\section{DIFFERENT MODES OF TERRORIST FINANCING}

Financing is essential for terrorist organizations and therefore suppressing the terrorist financing can effectively hinder the activities of terrorists. The terrorist activities can be either operational (surveillance, rehearsal, preparation, final attack etc.) or supportive (radicalization, recruitment, fund raising, training and travel etc) (Realuyo 2011). Different phases of terrorist financing process include the acquisition and extraction of finances from various sources, accumulation and security of funds during the planning and preparation of their utility and transfer of funds to the target spot when required. There have been different modes and techniques that are used by terrorists to acquire the funds and conceal their activities (OECD 2019).

The sources of funds used in the above context could be through use of apparently legitimate i.e. in the form of direct donations by individuals and organisations or explicitly illegal in the form of earnings from criminal activities. The sources of funding employed for terrorist activities may include inter alia donations from NGOs, welfare entities and foreign countries in form of salaries, welfare donations and business revenues. Under this category, individuals are 
persuaded to make donations from their personal or family sources of income on small scales in their neighbourhood communities or places of worship. However, fund raising on large scales is performed via internet which is achieved by making appeals on social media etc. Many Governments encourage the charities by allowing their taxpayers to deduct a percentage of their donations and the money trail becomes unidentifiable if the donations are done through cash transactions. So, the source, movement and the usage ofsuch funds cannot be tracked easily (OECD 2019).

The sector of funding and donation on call for "help the underprivileged" is very appealing and highly vulnerable for misuse and provides the major source for accumulating revenues to finance the terrorist organisations in performing terrorist activities which can range from a few thousand dollars to gigantic amounts. Some charity raising organisations have a global status and are working in collaboration with some other groups which are located near conflict areas where terrorist organisations may be more active. (OECD 2019). According to a report on Money Laundering typologies by Financial Action Task Force (2002-2003), some charity organisations served as a cover for transferring funds to support terrorist activities, on an international basis, in addition to serving as a direct source of income. According to the US Department of Justice, the Global Relief Foundation which was a charity organisation, sent more than 90 percent of its donations abroad and had connections to and provided assistance to individuals associated with Osama bin Laden, the al Qaeda network, and other known terrorist groups (Realuyo 2011).

Terrorist financing has made a direct linkage to Organised Crime as Funds are also collected through criminal activities which include fraud, drug trafficking, white collar crimes, extortion, State sponsorship and cyber crime. Foreign fighters and even native violent extremists tend to exploit public assistance programs and show fabricated reimbursements. These criminally earned assets are transferred through money laundering before being consumed in actual terrorist activities. Terrorist organisations also tend to confiscate large areas of public assets and natural resources within a territory. The resources like natural gas, mineral deposits, gemstones and precious metals then provide funds for 
terrorist activities by proceeding through black market which may be located outside of the territory where terrorists are positioned.

\section{MOVEMENT OF FUNDS}

All the funds collected through aforementioned sources can be stored not only in bank accounts but also in the form of pre-paid cards, valuable commodities such as used vehicles, gemstones and precious metals, art and agricultural products and crypto currencies. These funds are transferred through banking and financial sectors; licensed money service; remittances; informal value transfer systems like Hawala; and bulk cash smuggling as well as in form of foreign exchange and valuable goods. In case of Terrorist Organisations, the funds are used for administrative purposes; acquisition of weapons and related materials; media; messaging; recruitment; training; and financial support of the families of terrorists. Such finances are also utilised for travel of foreign fighters; their passport and visa costs; as well as maintaining their survival and trainings (OECD 2019).

Bulk cash smuggling and cash couriers an appealing mode of financing as US dollar being international currency can be easily converted. In this mode of cash transfer, the money trail cannot be traced easily because there is no documentation, written record keeping or third party involvement and it ensures complete control on cash movement by the terrorists. However, there is a risk of stealing on the way of courier and border control checking as well as involvement of informers (Realuyo 2011).

There is a type of alternative remittance system available that facilitates terrorist organisations called hawala. This informal banking system was traditionally used by expatriates labourers and traders and based on extensive connections like family relations and regional affiliations. These transfers take place through nonbank money services and prove to be efficient and cheap. The money is received to make an equivalent value payable to a third party who is located in another geographical area. Reportedly, Albarakat informal banking service 
facilitated Al-Qaida in Afghanistan. Informal Banking System proved to be challenging in countering terrorist financing (Realuyo 2011).

\subsection{Linkage between Terrorist financing and Money laundering}

Money laundering and terrorist financing are considered to be the offences that can possibly be interconnected specifically in the situation when funds transferred to terrorist organisation are "laundered" funds. So, money laundering and terrorist financing both have same features and typologies like secrecy and mobility, but the direction and timings of transactions are different. However, the concealing feature is not a part of terrorist financing up to the phase when funds are used.

Most evidently, efforts for countering the terrorist financing resemble the efforts for reduction of the money laundering. In both cases the rationale is same. Terrorists cannot operate without financial resources like other criminals so by limiting the available resources through CTF measures may control some attacks from taking place or atleast reduce the impact of attacks (Bures 2012).

\subsection{Financing of different organizations}

The terrorist organisations like Al-Qaida and ISIS have diversified their ways of financing with the passage of time essentially due to different evolving counter terrorist financing efforts. According to records Al-Qaida started working as an organised-criminal organisation and developed a complex system of financial management. It engaged itself in black market fuel sales, sales of stolen articles and also large scale embezzlements. Before 9/11 attacks, the primary source of funds for Al-Qaida was external donations extracted through benevolent charities. As external donations continue to be part of the cause for a number of al-Qaeda affiliates, they are pursuing more diverse charity tributaries and are increasingly drawing funds locally. It is estimated that Al-Qaeda has obtained about \$100 million in compensation for kidnapping (2008-2014) (Bauer 2017). In Iraq and Syria, ISIS took over a large area of territories by taking advantage of several pre-existing dynamics. They invaded masses of natural resources and a 
large population for economic activity, created smuggling networks and indulged in robberies of banks and valuable goods like machinery and weapons. It emerged as a source of serious concern for international community owing to the presence of its different franchises in eight countries across the Africa, Asia and Middle East in 2014. Most of these franchises were in fact in existence prior to ISIS and were primarily financed through crime, smuggling, extortion, and kidnapping for ransom. Some of these entities were motivated to affiliate themselves with the ISIS for additional resources in which it could not reportedly succeed (Bauer 2017).

The financial trail of $9 / 11$ attacks by Al Qaida exhibits how the hijackers living between common people achieved their goal. The 9/11 commission report showed that the whole plan charged Al-Qaida with approximately 400,000500,000 US Dollars. Around 300,000 US Dollars were deposited in US bank accounts in the name of nineteen hijackers. Al-Qaida provided the funds to the hijackers in US through wire transfers from overseas and transport of traveller's cheques. The hijackers then used the US banking system to make the transactions which shows that the existing banking system was not designed to identify or disrupt the transactions.

\section{UN INSTRUMENTS AGAINST TERRORISM FINANCING}

With the evolution of terrorist financing modes and techniques, the responses from the international community to prevent such threats also need adaptations. Following the 9/11 attacks in the US, the continued struggle of counterterrorist financing focused on identifying the sources of funds and disrupting the donors. In this manner, United Nations is playing a great role in deterring charity organizations from exploitation and diversion of funds to sustain terrorist causes. In order to adopt the best practices on international level, substantial efforts have been made. All the Member States under the flag of United Nations are gathered to make the international financial system impenetrable for terrorists financing activities. Most of the efforts in this regard are linked to enhancing awareness about the risks involved in supporting and financing of 
terrorists. Despite the risks of retaliation, the Member States are expected to implement paradigms of high-risk jurisdiction, applying sanctions and sharing important information to restrict the terrorists from earning, saving and transferring their assets (Bauer 2017).

The issue of Terrorist Financing has been at the core of UN's agenda as it is evident since the adoption of the International Convention for the Suppression of the Financing of Terrorism (Nations 1999) and UN Security Council resolution 1373 (Council 2001). UN General Assembly assigned the Ad Hoc Committee with formulating a draft as there was an urgent need to enhance international cooperation regarding the countering of terrorist financing. The question of how an ancillary act of financing could be regarded as crime of terrorist financing was intended to address by proposing the draft for this resolution. The approaches of treating terrorist financing as an ancillary form of participation in the offence of terrorism, criminalizing only the acts of financing of terrorist groups and to consider terrorist financing as an independent crime were the main proposed approaches (Tofangsaz 2018).It finally led to the adoption of the UN International Convention for the Suppression of the Financing of Terrorism in 1999.According to this Convention, the Member States could prosecute direct or indirect financing of terrorist acts on their territory (Nations 1999). The Convention defines the crime of terrorist financing as an offense committed by any person if "that person by any means, directly or indirectly, unlawfully and wilfully, provides or collects funds with the intention that they should be used or in the knowledge that they are to be used, in full or in part, in order to carry out an act, intended to cause death or serious bodily injury to a civilian, or to any other person not taking an active part in the hostilities in a situation of armed conflict, when the purpose of such act, by its nature or context, is to intimidate a population, or to compel a government or an international organisation to do or to abstain from doing any act"(Nations 1999). So, the Convention imposed an international obligation upon States to identify a set of terrorist related offences as crimes in their domestic laws (Al-Khulaifi 2018).

UN General Assembly had to formulate several subsidiary bodies due to increase in terrorist activities and evolution of new and advanced techniques of 
terrorist financing and support. It also adopted "the Global Counter terrorism Strategy (UNGCTS)" which has huge significance in the efforts aimed at countering terrorism and suppressing all the aspects linked with it such as financing and supporting the terrorists and their activities, within the territories of States and through cooperation at regional and global levels. UNGCTS comprising four sets of measures emphasized on the coordinating role of United Nations for the international community. In order to prevent terrorist financing, drug trafficking and weapons of mass destruction, it emphasizes a need of intergovernmental cooperation and also the supervisory role of the UN Security Council in implementing the obligations concerning counter terrorism and combating terrorist financing. The need for enhancing the cooperation between States and organisations regarding financial systems like World Bank and International Monetary Fund, continuous strategy analysis and dealing with identified shortcomings in implementation of measures, to counter terrorist financing most effectively, was also focussed. NGOs were also invited to assist in implementation of the Strategy. United Nations Office on Drugs and Crimes (UNODC) was also instructed to join for the technical assistance program. The ambition was to make the measures easier and effective for implementation by the international community to suppress the misuse of charity organisations by terrorists for financing the terrorist activities (Klemar 2017).

The UN Security Council revealed a growing concern and recognised the phenomenon of terrorism and specifically terrorist financing as the greatest threat to international security after 9/11. The need to criminalize terrorism, freezing the assets of terrorists and introducing the disruptive measures in terrorist activities were given particular significance. The United Nations Security Council has subsequently adopted a series of key resolutions on the criminalization of the financial support to terrorist organizations, including AlQaida and ISIL. UNSC Resolution 2178 (2014) was adopted on the financing of the travel of foreign terrorist fighters. This Resolution condemned financing of terrorism and called upon the States to prevent "recruiting, organising, transporting or equipping of individuals who travel for the purpose of the perpetuation, planning of, or participation in terrorist acts, associated with ISIL, 
Al-Nusra Front [ANL] and other affiliates or splinter groups of Al-Qaeda" (S. Council 2014).

UNSC Resolution 2199 (2015) was adopted on the criminalization of any direct or indirect trade involving ISIL as well as UNSC Resolutions 2368 (2017) and 2396 (2017) also focussed on terrorist financing. All these UNSC resolutions were approved under Chapter VII of the United Nations Charter and created an obligation for the Member States to implement appropriate course of action and also highlighted the requirement of identifying and assessing the risks of terrorist financing within their economies (UNODC 2018).

The UN Security Council also established the Security Council Committee pursuant to its resolutions 1267 (1999), 1989 (2011) and 2253 (2015) concerning ISIL (Da'esh), Al-Qaida, and associated individuals, groups, undertakings and entities (UNODC 2018).

UNSC Resolution 1267 was of great significance as it deviated from other soft law instruments established by United Nations before $9 / 11$ and invoked chapter VII of the United Nations by making it binding for all the Member States and sanctioned the Taliban regime in Afghanistan. It also made it obligatory for the Member States to freeze the funds, financial resources and other assets that belonged to Taliban as well as prevent citizens and foreign nationals in the territories of the Member States from involvement in terrorist financing.

UNSC Resolution 1373 is another important instrument to deal with terrorist financing. It emphasized on harmonizing international cooperation in combating terrorism, through obligation on States to assist other States in the investigation procedure in order to collect proof on financing the terrorist acts, sanctioned State-sponsored terrorism and made obligations on States to not only freeze assets of persons involved in terrorist financing but also amend their criminal legislation to sanction the individuals, groups and entities linked to terrorist financing. The criminalization of financing includes funds and donations either directly or indirectly intended for terrorism financing. However, some sources like ransom for kidnapping and exploitation of natural resources are also included recently. UNSC Resolution 1373 also recommended the formation of Counter-Terrorism-Committee (CTC) which comprised of representatives of all Security Council members. CTC was formulated to 
provide support in enhancing their capability of fighting terrorism and all the challenges linked with it like overcoming the facilitation and financing of terrorism. CTC also takes overview of the difficulties faced by the Member States in countering and combating terrorism and financing of terrorism. It also suggests the UN Security Council to formulate the best measures for overcoming the difficulties and challenges encountered by the Member States in suppressing terrorist financing. In assessing the level of implementation of binding measures, CTC can suggest the changes and modification in domestic legislation of a State to conform to the recommendations of the resolution. This provides the way for creating tailor-made provisions in compliance with the specific conditions and requirements of different regions. In 2004, CTC was recommended to visit the Member States to provide more efficient ways of assistance and also to cooperate with other bodies of United Nations for which purpose CTC was restructured to join with special Bureau and the Counter Terrorism Executive Directorate (CTED).In building an effective system and facilitating more efficient freezing of assets of individuals and organisations involved with terrorism, the Security Council created a Working Group for the implementation of Resolution 1566 dealing with measures for combating individuals, terrorist organisations and related persons (Klemar 2017).

Sanctions imposed by UNSC resolution 1267 and other related resolutions are against sale and supply of arms, military vehicles and other equipment to the Taliban regime, Osama bin Laden, Al-Qaida and other individuals and organizations involved in terrorist activities. UNSC Resolution 1373 is of a different nature and scope requiring States to take intensive actions to prevent support and funds to terrorist organizations andcriminalizes terrorist financing along with freezing all assets related to them immediately. However, this resolution does not institute a list of individuals or organizations considered as terrorists. It keeps it open for each State to make this determination and to take appropriate measures (Jean-Francois Thony 2007).

\subsection{Challenges in implementation of UNSC resolutions}


The absence of a legal framework in many States to implement the provisions of the UNSC resolutions is one of the key challenges. The changes and adaptations in the National legislation framework is a vital step to be taken by the States. Banks and financial institutions holding the accounts may have a reluctance to use the above resolutions. So, there is a need of establishing a national authority with the responsibility to monitor the implementation of the UN resolutions.

The establishment of a sanction system in case of violation of the obligations by a person and instituting of a mechanism to ensure the freezing process by financial institutions is highly recommended by UN resolutions. UNSC Resolution 1267 and other subsequent resolutions did not provide any time frame for which the freezing of assets should be carried out. Setting a timeframe is important for freezing of accounts and a procedure is required for lifting the freezing of assets of the individuals or organizations that are considered to be involved in financing of the terrorist acts (Jean-Francois Thony 2007).

It is also of great importance to be in line with existing national risk assessment guidance which is provided by United Nations Office on Drugs and Crimes and other UN bodies which are assigned according to a specific state's circumstances. There are three stages of a risk assessment; identification, analysis and evaluation. A risk assessment is important as it takes an all inclusive approach to analyse the short comings in implementation of UNSC resolutions in a specific region or area. So, the risk assessment covers the latest developments regarding criminal activities and their complete analysis. It also analyses the capacity and needs of competent authorities which are involved in combating terrorist financing, law enforcement agencies complemented by qualitative information. Moreover, it can also use the information provided by independent and external studies and public information on vulnerability to terrorist financing.

The first stage in terrorist financing risk assessment is the identification of the criminal environment including the security information and terrorism profile of a specific country which is under analysis. A complete understanding of the criminal activities taking place in a given country is important for an effective terrorist financing risk assessment of that specific country or region where terrorist financing acts are committed and proceeds of criminal acts are 
laundered. In order to gather information on criminal environment of a specific country, it is essential to collect the general and specific information on the size of illegal activities. Identifying the national threats by analysing the quantitative data on progress in crimes and prosecution information is fundamental to the process of risk assessment. If the quantitative data is missing or keeping the quantitative record is not a part of a country's legislation then qualitative data and expert's opinion can serve the purpose. Many States have shared their information in this regard with the countries in close security partnership. The security environment information and terrorism profile need to be shared by neighbouring countries when a regional risk assessment of terrorist financing is required. So, the sharing of information between UN Member States is particularly developed in case of regional risk assessment. In many cases of terrorist attacks recently, it appeared that the terrorists had a criminal record of being involved in theft, drug trafficking and selling imitation goods. Moreover, weapons and other materials are found to be provided by criminal groups to the terrorist groups.

The next important step in terrorist financing risk assessment is the identification of the threats that the country or region is facing. It is of utmost importance to compile a list of potential terrorist financing threats and vulnerabilities, the important sections exploited for terrorist financing and the reasons why those are not intercepted or deprived of illegal assets.

Vulnerabilities are also identified in terrorist financing risk assessment. Vulnerabilities refer to gaps or weaknesses in a country's measures against terrorist financing. Identification of these vulnerabilities and addressing them effectively is of paramount importance. The measures against moneylaundering or terrorist financing may include the elements like reporting entities' ownership controls, record of identification documents and financial transactions records with customers, suspicious financial transactions reports, counter-terrorist financing supervision and the country's administrative sanction framework. The analysis of suspicious transactions, international cooperation with financial intelligence units and non-financial intelligence entities and national cooperation with competent authorities are also included in preventive measures. The investigative and criminal frameworks in a State 
include the effectiveness of the analysis of suspicious transaction reports, investigative techniques and the dedication of resources. Moreover, the effectiveness of the cooperation with other authorities, the capacity to punish perpetrators of terrorist financing activities and the capacity to confiscate assets issued from criminal activities or aimed at financing terrorist activities also play a key role as preventive measures (UNODC, Guidance manual for Member States on terrorist financing risk assessments 2018).

\section{CONCLUSIONS}

The inability of the United Nations in formulating a commonly agreed upon definition of "terrorism" has had a huge impact on effectively countering terrorist financing. Furthermore, the difficulty in concluding an agreement on a broad and reliable definition of terrorism led initially to the adoption of a thematic approach to suppress terrorism and terrorist financing. Therefore, the international conventions were negotiated mainly on certain categories of offenses without defining the term 'terrorism'. However, the intent element in the favor of 'sharply narrowed and highly elaborated' material elements made the conventions and acts criminalized by them vulnerable to criticism of being sectoral and based on personal and material causes (Tofangsaz 2018).

CTF efforts proved to be useful in many cases for tracing operatives of crime and for finding connections between individuals involved in terrorist financing. A financial record is much more reliable than other forms of intelligence when there is a need to reconstruct events after terrorist attacks and better understand the modus operandi of a terrorist group or organization (Bures 2012).

It would not be justified to remark the UN counter terrorism legal framework as totally unsuccessful. Despite, its limitations, this framework has established an important foundation on which further improvement can be made. However, for doing so, it is important to underscore that there remains space for more area specific and tailor-made drafting of such legal framework enabling it to deal with all the challenges related to a specific geographical region. The 'one fits for 
all' approach cannot be justified as every geographical region has its own specific requirements. Furthermore, in order to limit the ability of terrorists and their organisations to get their required finances, there is a need to apply a series of actions universally which would also require a new international legal framework. It may be highlighted that the issue of Human Rights of victims of terrorism is also an important aspect to be addressed while countering the acts of terrorism and terrorists financing. United Nations Global Counter Terrorism Strategy adopted by UN General Assembly is an appreciable step taken in this regard which clearly identified this issue. This is also emphasized by UN Legal Counsel and by the adoption of UNSC Resolution 1730. However, more needs to be done in this regard as well.

\section{REFERENCES}

- Al-Khulaifi, Mohammed A. 2018. "Terror Financing: A Crime That Requires Global Responses." Qatar Tribune. 16 April.

- Bauer, Katherine. 2017. "The Evolution of Methodologies in terrorist financing." Strategic Sectors, Security \& Politics. IeMed Mediterranean Year Book 2017

- Bures, Oldrich. 2012. "Private Actors in the Fight Against Terrorist Financing: Efficiency Versus Effectiveness." Studies in Conflict $\mathcal{E}$ Terrorism: 712-732.

- Jean-Francois Thony, Cheong-Ann Png. 2007. "FATF Special Recommendations and UN Resolutions on the financing of terrorism." Journal of financial crime: 150-169.

- Johnson, Jeffery M. \& Carl Jensen. 2010. “The Financing of terrorism." The Journal of Justice \& International studies. 10.

- Keohane, Robert O. 2009. "The contingent legitimacy of multilateralism." In Multilateralism under challenge: power, international order and structural change, by Ramesh Thakur and John Triman Edward Newman. 
- Kovač Klemar, Tatjana, Miran Marelja. 2017. "Institutional Support for Terrorist Financing Prevention." Athens Journal of Law: 27-50.

- Nicholas Ridley, Dean C. Alexander. 2012. "Combating terrorist financing in the first decade of the twenty-first century." Journal of Money Laundering Control: 38-57.

- OECD. 2019. "Money Laundering and Terrorist Financing Awareness Handbook for Tax Examiners and Tax Auditors." Paris: OECD. www.oecd.org/tax/crime/money-laundering-and-terrorist-financingawareness-handbook-for-tax-examiners-and-taxauditors.pdf.

- Realuyo, Celina B. 2011. "Following the Terrorist Money Trail." The Quarterly Journal.

- Romaniuk, Peter. 2010. Multilateral Counter terrorism, the global politics of cooperation and contestation. New York: Routledge.

- Shillito, Matthew Robert. 2015. "Countering Terrorist Financing via NonProfit Organisations: Assessing why few States Comply with the International Recommendations." De Gruyter: 325-352.

- Tofangsaz, Hamed. 2018. "Criminalization of terrorist financing: from theory to practice." New criminal law review: 57-140.

- UNODC. 2018. "Guidance manual for Member States on terrorist financing risk assessments." Vienna: United Nations.

- United Nations. 1999. “United Nations treaty collection." New York, 9 December.

- United Nations Security Council. 2014. "UNSC Resolution 2178.". 24 September.

- United Nations Security Council. 2001. "UNSC Resolution 1373." 28 September.

- "Guidance manual for member states on terrorist financing risk assessments." 2018. Vienna: United Nations. 